\title{
Generation of Ideas, Ideation and Idea Management
}

\begin{abstract}
Ideas are vital for organizations because they are the source for innovation and this in turn is endless source of competitive advantage. The correct definition of concepts not only allows the targeting of academic studies, but its future application in everyday life of organizations. The overall objective of this article is to clarify the terms related to generation of ideas, ideation and idea management. The method used was a literature review, and later, an analysis of the concepts used by the studies surveyed, seeking points of convergence and divergence. As a result we propose a clarification in order to aid understanding of the terms, setting a benchmark for future research. We conclude that ideation and idea generation are the same, they are the process of creating new ideas and idea management comprises the management of ideas throughout the innovation process.
\end{abstract}

Keywords: Innovation, Generation of ideas, Ideation, Management ideas.

\section{Geração de ideias, ideação e gestão de ideias}

\section{Resumo}

Ideias são vitais para as organizações, pois elas são a fonte para a inovação, e esta, por sua vez, é fonte inesgotável de vantagem competitiva. A definição correta de conceitos possibilita não somente o direcionamento de estudos acadêmicos, mas a sua futura aplicação no cotidiano das organizações. O objetivo geral deste artigo é clarificar os termos relacionados à geração de ideias, ideação e gestão de ideias. O método utilizado foi um levantamento bibliográfico e, posteriormente, uma análise dos conceitos utilizados pelos estudos levantados, buscando pontos de convergência e divergência entre os conceitos. Como resultado propõe-se uma clarificação que visa auxiliar o entendimento dos termos, preparando um referencial para pesquisas futuras. Conclui-se que a ideação e a geração de ideias são o mesmo, ou seja, elas são o processo de criação de novas ideias e a gestão de ideias compreende o gerenciamento das ideias ao longo de todo o processo de inovação.

Palavras-chave: Inovação, Geração de ideias, Ideação, Gestão de ideias.

Patrícia Fernanda Dorow patrciadorow@gmail.com Master in Engineering and Knowledge Management from Universidade Federal de Santa Catarina; Doctoral Candidate in Engineering and Knowledge Management at Universidade Federal de Santa Catarina; Researcher at Nucleus of Sustainability Management (NGS/UFSC)

Guillermo Dávila

davila.guillermo@gmail.com Master in Engineering and Knowledge Management from Universidade Federal de Santa Catarina; Doctoral Candidate in Engineering and Knowledge Management at Universidade Federal de Santa Catarina; Researcher at Nucleus of Sustainability Management (NGS/UFSC)

Gregório Varvakis grego@gmail.com

PhD in Manufacturing Engineering -Loughborough University, England; Researcher at Nucleus of Sustainability Management (NGS/UFSC); Associate Professor at Universidade Federal de Santa Catarina, Department of Knowledge Engineering Rolando Vargas Vallejos valejos@gmail.com PhD in Production Engineering from Universidade de Caxias do Sul; Professor at Universidade de Caxias do Sul - UCS; Coordinator of the Program of; Technological Education of Universidade de Caxias do Sul;Member of COVE (Cooperation Infrastructure for Virtual Enterprises and electronic Business) 


\section{Introduction}

It is currently accepted that the development and diffusion of new technologies are essential for the growth of output and productivity growth (Organization for economic co-operation and development, 2005). In this new knowledge society in which we live, knowledge became the main production resource. During the organization of Taylorist production of the twentieth century, focus was in the manpower, whereas nowadays focus is in the brain labor, which has greater knowledge and ability to generate innovative ideas as main inputs (Vygotsky, 2007).

In the current economic context, knowledge is key to achieving improvements and overcoming difficulties. Thus, innovation is part of the core of the new company, called knowledge society (Porcaro, 2001). Despite this recent attention given to innovation, there are still many uncertainties and much to study in this field (Brun, Saetre \& Gjelsvik, 2009).

One realizes that innovation was fostered by the effect of globalization, where increased competition has made firms ran out of time to upgrade their product offerings, expand their capacity, reach new markets and thus remain competitive (Reid \& Bretani, 2004).

The first definition of innovation was stated by Schumpeter in the late 1920s and emphasized the aspect of doing things differently (Crossan \& Apaydin, 2010). Understanding the innovation process and reducing its uncertainties became crucial in recent years for the companies to innovate, in order to improve productivity and rates of growth (Chang, Chen \& Wey, 2007).

Innovation then becomes the agenda of companies, becomes the object of study in academia and focused research projects (Tidd, Bessant \& Pavitt, 2008). These authors also point out that innovation does not only occur at random and unstructured in diffuse processes. It must be part of a business strategy, be well defined and planned, as it is a diverse complex activity, where various elements interact. Alam (2006) suggests that the process of innovation may be less pervasive if customers are involved from the earliest stages of development.

In the literature about the ideas in the innovation process, there are three terms: ideation, idea generation and idea management. However, some authors (Flint, 2002;. Bocken et al., 2011) present ideation and idea generation with the same or very similar meanings, and others (Flynn et al., 2003.) do the same thing with idea generation and management of ideas. So, there is a need for clarification of these concepts, given that a clear understanding facilitates both the generation of knowledge and its application. Thus the overall goal of the article was to clarify the terms related to the generation of ideas, ideation and idea management.

The paper is structured as follows: first a review of literature on idea generation and idea management is performed. After the methodology used in the research is described.It is followed by an analysis and discussion of the results and finally the concluding remarks of the study are presented.

\section{Literature Review}

\section{Generation of Ideas}

Generating ideas is the systematic process of creating and capturing ideas in accordance with the requirements set by the organization, and it includes elements related to creativity and details of the organizational structure to support the process (Flynn et al., 2003; Björk et al., 2011; Cooper, 2001). Girotra, Terwiesch and Ulrich (2010) claim that almost all innovation processes include idea generation and selection of ideas or opportunities. Boeddrich (2004) emphasizes that all innovation is based on an idea that can be inside or outside the company.

Verworn (2006) reports that domestic inputs are the main sources of generating ideas, and highlights areas of marketing, sales, senior management and $R \& D$ inputs as great ideas. External sources can happen in the form of participation by customers who have their desires, their needs and to their solutions for possible products. Competitors may also provide new ideas. The knowledge of a competitor's product can instigate a team to create a new product or improve a product already marketed by the company (Cooper \& Edgett, 2007).

Techniques and tools can be used to help in generating ideas. They increase the number and quality of ideas generated (McAdam \& Mcclelland, 2002). Thus, the generation of ideas is essential in the innovation process, and, according to Miguez (2012), the person responsible for applying a session to generate ideas can, based on his/her experience, choose one of several techniques to be applied according to the profile of the company. 


\section{Management ideas}

Often, generating ideas is not the biggest problem, but selecting the ideas that are more aligned to the mission, vision and values of the company, so that these can materialize into successful innovation (Reitzig, 2011). In the process of selection of ideas, a first filtering of ideas is performed which will be subjected to various evaluation criteria (Cooper \& Edgett, 2009). Since the processes of choosing ideas in the initial phase are critical due to the scarcity of information, accuracy in the selection of ideas in the initial phase should be smaller than in the development phase, otherwise any good idea can be lost due to their uncertainties (Koen et al., 2001). Thus, the organization must have formal processes to evaluate these ideas still in the initial phase as well as resources such as time, money and people able to perform this selection, so that, later, the best ideas are developed (Koen et al., 2002).

According to Cooper and Kleinschmidt (1993, p. 26.), "The biggest differences between winners and losers were found in the quality of pre-development activities." In addition, the generation of ideas, with no focus, is useless for business. Moreover, the machines are unable to duplicate certain functions of the creative human brain. Boeddrich (2004) states that the two ways of generating ideas are flawed and doomed to failure. They need to be combined through an innovative approach.

On the one hand, the phase of gathering ideas for the decision of a central idea should be structured so that ideas can be openly identified with a variety of ideas. On the other hand, the evaluation and development of the ideas could be based on contextual rules - defined by the enterprise (Geschka \& Schwarz-Geschka, 2000). For a management system oriented to produce structured ideas, it is necessary to distinguish between the general requirements of the organization and the specific requirements of the company (Cooper, 1996; Ernst, 2001; MontoyaWeiss \& Calantone, 1994). The same authors confirmed these requirements in their studies as follows:

General requirements:

a) the existence of strategic guidelines for innovations;

b) installation of a collection point for broad ideas;

c) systematic collation of ideas;

d) feature of decision making;

e) Pre-defined and transparent selection criteria and implementation of ideas;

f) function funnel to the selection process;

g) simple systems for easier management.

Specific requirements:

a) defined by the company specifying categories;

b) the company's commitment to review the methods and criteria especially with regard to the criteria of the approved projects;

c) copyright;

d) commitment to certain individuals or organizational units that promote innovation within the company;

e) definition of creative scope for the company;

$\mathrm{f}$ ) influence of top management in the Front End Innovation (FEl);

g) number of stages and specific gates for the management of ideas;

h) investigate the stakeholders in structuring the front end of innovation and declaration of their participation.

The lack of systematic and well-structured steps at the beginning of the innovation process procedures has detrimental effect on innovation management, because it is difficult to develop strategies for innovations when they are already in development (Alves et al., 2007). When the company does not have a criteria for selection of ideas, lots of ideas without prospects continue to be discussed for a long time, wasting physical and emotional (McAdam \& Leonard, 2004) resources. Time is also lost, difficulting the execution of learning processes needed for improving innovation procedures (Björk \& Magnusson, 2009).

The evaluation phase of the idea consists of several stages where ideas need to be analyzed and enriched (Cooper, 2005). Upon receipt of the selected ideas, it is important that their choice is made efficiently taking into account the company's priorities and resources (Aeberhard \& Schreier, 2001). The ultimate success of management depends largely on the ideas of these alignment with the company's structure as well as the proper implementation corresponding to the organizational structure (Voigt \& Brem, 2005). 


\section{Methodology}

The research was carried out in three different stages: data collection, literature review and analysis of concepts. It follows a qualitative and exploratory approach based on bibliographic sources. Thus, research from sources such as books and recent publications in journals allowed to gather information on the topics generating ideas, ideation and idea management in order to understand the phenomenon and describe the process (Santos, 2000).

A search was carried out in the Scopus database with the terms + innovation idea generation, in the titles, abstracts and keywords. The English terms were used to provide greater coverage of search.

Following the analysis of keywords found in the search in the Scopus database, another search was made for the following terms combined with innovation: basic idea; creative ideas; idea generation; idea generations; idea management; idea selection; idea screening; ideas; ideation; ideas generation; innovative ideas; new ideas. These searches were conducted on four databases in June 2012: Scopus, Web of Knowledge, EBSCO and Engineering Village.

We decided for the use of journal articles and books. Eighty-three articles that brought the concept of the term or any explanation that could help their understanding, and they were classified according to the terms they dealt with: idea generation and ideation; generation of ideas, ideation and idea management.

\section{Discussion and analysis of results}

This section aims to clarify the concepts related to ideas: idea generation, idea management and ideation. For this, an analysis of concepts in articles dealing ideation, idea generation and idea management was performed. Accordingly, this set of articles in the databases was reviewed, conducting crosses between data in order to enhance convergence and divergence, as well as build a proposed clarification for terms, according to the studies analyzed.

Based on the portfolio of the pre-selected articles a more detailed analysis of the work containing the concept or an explanation of at least one of the three following terms was performed: generation of ideas, ideation ideation or idea management. Eighty-three articles that brought the concept of the term or any explanation that could help their understanding, being classified according to the terms that were explored: idea generation and ideation; generation of ideas, ideation and idea management. In Figure 1, we visualize the division of authors according to this classification.

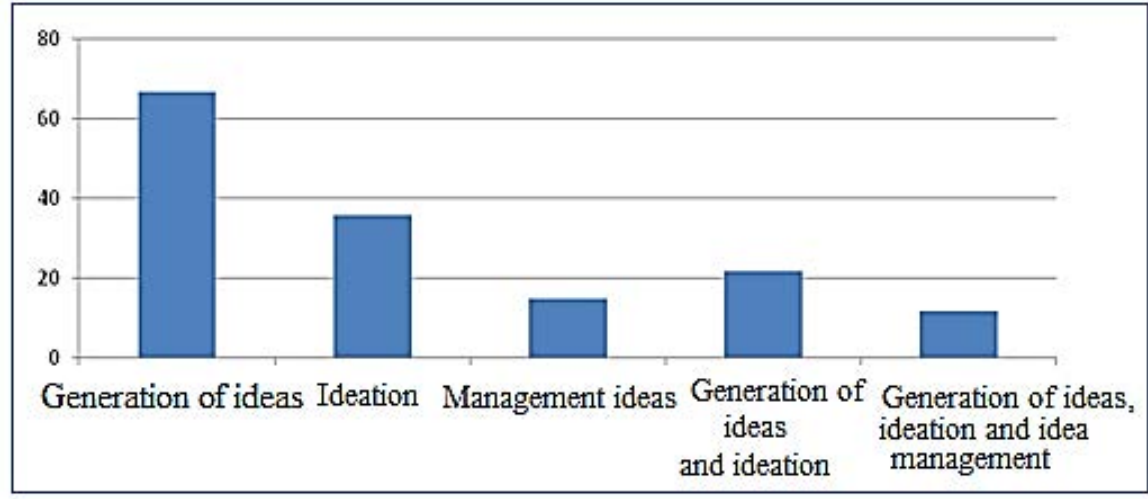

Figure 1. Frequency Division under the term use Source: Compiled by author

It is noticed that most studies (67, that represent $80 \%$ of total analyzed) use only the term generation of ideas, the term ideation alone was used in $36(43 \%)$, and $22(27 \%)$ use ideation and idea generation with the same or very similar meanings. Only $15(18 \%)$ use idea management, and $12(14 \%)$ use generation ideas, ideation and idea management as being the same thing. During the research, we observed a variety of definitions of the concepts of idea generation, idea management and ideation, as can be seen in Figures 2, 3 and 4.

Aiming to a standardization and clarification of terms, an analysis of the concepts / understandings with respect to the generation of ideas (Figure 2), with suicidal ideation (Figure 
3) and the idea management (Figure 4) was performed, considering the context of each article. Furthermore, this analysis of concepts was based on the innovation research of Smith and Reinertsen (1991), which divides the process in three sub innovation model: FEl, new product development and marketing.

\begin{tabular}{|c|l|}
\hline Authors & \multicolumn{1}{c|}{ Understanding concerning } \\
\hline Diehl e Stroebe (1991) & Is considered a task, part of the ideation process, responsible for the idea itself. \\
\hline Alam (2003) & $\begin{array}{l}\text { The intensity of interaction among agents during the process of generating ideas } \\
\text { increases the chances of the emergence of new ideas. }\end{array}$ \\
\hline Sensiper et al. (2003) & Patterns of relationships between organizational actors directly affect this process. \\
\hline Flynn et al. (2003) & For this process, brainstorming is the most suitable technique. \\
\hline Björk et al. (2011) & $\begin{array}{l}\text { The greater the number of structural holes in the network, the lower the quality of } \\
\text { ideas. }\end{array}$ \\
\hline
\end{tabular}

Figure 2. Concepts / understandings with respect to the generation of ideas Source: Compiled by author

\begin{tabular}{|c|l|}
\hline Authors & \multicolumn{1}{|c|}{$\begin{array}{c}\text { Concepts / understanding relating to } \\
\text { IDEATION }\end{array}$} \\
\hline $\begin{array}{c}\text { Dugosh \& Paulus } \\
\text { (2005) }\end{array}$ & The process of organizing the ideas for the innovation process. \\
\hline Björk et al. (2011) & Production and handling of new ideas. \\
\hline Bocken et al. (2011) & $\begin{array}{l}\text { Generation of ideas, complex and contextually specific involving all phases rela- } \\
\text { ted to process ideas. }\end{array}$ \\
\hline Briggs \& Reinig (2010) & To generate useful ideas to achieve some desired state or outcome process. \\
\hline $\begin{array}{c}\text { Björk, Boccardelli \& } \\
\text { Magnusson (2010) }\end{array}$ & Identification of ideas generation and explicit formulation of ideas. \\
\hline Briggs \& Reinig (2010) & Process to gain a desired result or state. \\
\hline $\begin{array}{c}\text { Cooper \& Edgett } \\
(2012)\end{array}$ & Creation of new process ideas. \\
\hline
\end{tabular}

Figure 3. Concepts / understanding relating to ideation Source: Compiled by author

\begin{tabular}{|c|l|}
\hline Authors & \multicolumn{1}{|c|}{$\begin{array}{c}\text { Concepts and understandings relating to } \\
\text { MANAGEMENT IDEAS }\end{array}$} \\
\hline Brem \& Voigt (2007) & $\begin{array}{l}\text { Identify ideas, generate and evaluate a part of a sub process of innovation mana- } \\
\text { gement with the goals of idea generation, evaluation, and effective and efficient } \\
\text { selection. }\end{array}$ \\
\hline Rochford (1991) & $\begin{array}{l}\text { Evaluation of new ideas, concept generation during the identification and selec- } \\
\text { tion of those ideas that need extensive analysis. }\end{array}$ \\
\hline Alam (2006) & $\begin{array}{l}\text { Part of the concept generation and analysis phase, filter and select the most } \\
\text { promising ideas. }\end{array}$ \\
\hline Berman \& Kim (2010) & Is present in all stages of the innovation process. \\
\hline $\begin{array}{c}\text { Ardaiz-Villanueva et al. } \\
(2011)\end{array}$ & Is to encourage, collect, evaluate, direct and shape ideas. \\
\hline $\begin{array}{c}\text { Bommer \& Jalajas } \\
(2004)\end{array}$ & It is present in all phases of the innovation process. \\
\hline
\end{tabular}

Figure 4. Concepts / understanding regarding the management of ideas Source: Compiled by author

From this analysis, we developed a clarification of the concepts of idea generation, idea management and ideation, as shown in Figure 5. Managing ideas is a more generic term and refers to the management of ideas throughout the process innovation. Ideation is an activity that 
involves the FEl (front end of innovation) motivation, creation, communication, evaluation and selection of new ideas focusing on the definition of concepts to the next subprocess: new product development. The generation of ideas is a task of ideation, in which ideas are created.

\begin{tabular}{|c|c|}
\hline Terms & Clarification \\
\hline $\begin{array}{c}\text { Ideation (idea } \\
\text { generation) }\end{array}$ & $\begin{array}{r}\text { Process of creating ideas. Involves motivation, creation, communication focused } \\
\text { on defining concepts for the next sub-process innovation. }\end{array}$ \\
\hline Management ideas & $\begin{array}{r}\text { Refers to the management of ideas, their management throughout all stages of } \\
\text { the innovation process involving the generation, enrichment, evaluation and } \\
\text { selection of ideas process. }\end{array}$ \\
\hline
\end{tabular}

Figure 5. Clarification of concepts Source: Compiled by author

It was found that there is lack of consensus among authors regarding the meaning of the terms: idea generation, idea management and ideation.

In addition, it was observed that ideation and idea generation are two concepts which have the same meaning, when referring to the process of generating new ideas. Also, there is a convergence in the literature about the relevance of some creativity techniques to assist the idea generation process.

Idea management comprises the management of ideas throughout the innovation process, thus having a wider character from generating by engaging to the selection ideas.

\section{Conclusions}

The literature has shown lack of consensus among authors regarding the meaning of the terms generating ideas, ideation and idea management. Thus, from the literature review, a clarification of concepts focusing on these three terms was proposed to facilitate both academic research as well as management application.

We conclude that both ideation and idea generation are referred to the process of generating new ideas. To assist this process, some creativity techniques can be used.

Idea management comprises the management of ideas throughout the innovation process, thus having a wider character from generating by engaging to the selection ideas.

One limitation of the research, points out the question of ideas and related terms, as these were found only in the context of innovation. But ideas are used throughout the organization, not just in the innovation process. For future research, it is proposed to study the differences and similarities in the management of ideas within and outside of the innovation process.

\section{Acknowledgments}

The authors would like to thank CAPES PEC-PG for their financial support through a PEC-PG scholarship to Guillermo Dávila. 


\section{References}

Aeberhard, J., \& Schreier, T. (2001). Management von Innovations prozessen. Retrieved from http://www. innopool.ch/pdf/I-Ae-Schr-01-Innoprozesse.pdf.

Alam, I. (2003). Commercial innovations from consulting engineering firms: An empirical exploration of a novel source of new product ideas. Journal of Product Innovation Management, 20(4), 300-313.

Alam, I.(2006). Removing the fuzziness from the fuzzy front-end of service innovations through customer interactions. Industrial Marketing Management, 35(4), 468-480.

Alves, J. et al. (2007). Building creative ideas for successful new product development. In: EUROPEAN CONFERENCE ON CREATIVITY AND INNOVATION (ECCI), Lodz

Ardaiz-Villanueva, O. et al. (2011). Evaluation of computer tools for idea generation and team formation in project-based learning. Computers and Education, 56(3), 700-711.

Berman, E. M., \& Kim, C.-G. (2010). Creativity management in public organizations: jump-starting innovation. Public Performance \& Management Review, 33(4), 619-652.

Björk, J. et al. (2011). The impact of social capital on ideation. Industry and Innovation, United Kingdom, 18(6), 631-647.

Björk, J., Boccardelli, P., \& Magnusson, M. G. (2010). Ideation capabilities for continuous innovation. Creativity \& Innovation Management, Malden, 19(4), 385-396.

Björk, J., \& Magnusson, M. G. (2009). Where do good innovation ideas come from? Exploring the influence of network connectivity on innovation idea quality. Journal of Product Innovation Management, 26(6), 662-670. .

Bocken, N. M. P. et al. (2011). Development of an eco-ideation tool to identify stepwise greenhouse gas emissions reduction options for consumer goods. Journal of Cleaner Production, 19(12), 1279-1287.

Boeddrich, H. J. (2004). Ideas in the workplace: a new approach towards organizing the fuzzy front end of the innovation process. Creativity and Innovation Management, 13(4), 274-285.

Bommer, M., \& Jalajas, D. S.(2004). Innovation sources of large and small technology-based firms. IEEE Transactions on Engineering Management, 51(1), 13-18.

Brem, A., \& Voigt, K. I. (2007). Innovation management in emerging technology ventures: the concept of an integrated idea management. International Journal of Technology, Policy and Management, 7(3), 304-321.

Briggs, R. O., \& Reinig, B. A. (2010). Bounded ideation theory. Journal of Management Information Systems, 27(1), 123-144.

Brun, E., Saetre, A. S., \& Gjelsvik, M. (2009). Classification of ambiguity in new product development projects. European Journal of Innovation, 12(1), 62-85.

Chang, S. L., Chen, C. Y., \& Wey, S. C.(2007). Conceptualizing, assessing, and managing front-end fuzziness in innovation/NPD projects. R\&D Management, 37(5), 469-478.

Cooper, R. G. (1996). Overhauling the new product process. Industrial Marketing Management, 25(6), 465-482.

Cooper, R. G. (2001). Winning at new products: accelerating the process from idea to launch. Cambridge: Perseus.

Cooper, R. G. (2005). Product leadership. New York: Basic Books.

CoopeR, R. G., \& Edgett, S. J. (2007). Generating breakthrogh new product ideas. Canada: Product Development Institute.

Cooper, R. G., \& Edgett, S. J. (2009). Successful product innovation: a collection of our best. Charleston: Booksurge. 
Cooper, R. G.\& Edgett, S. J. (2012). Ideation for Product Innovation: What are the best methods? Canada: Product Development Institute.

Cooper, R. G.,\& Kleinschmidt, E. J. (1993). Uncovering the keys to new product success. IEEE Engineering Management Review, 21(1993), 5-18.

Crossan, M. M., \& Apaydin, M. (2010). A multi-dimensional framework of organizational innovation: A systematic review of the literature. Journal of management studies, 47(6), 1154-1191.

Diehl, M., \& Stroebe, W. (1991).Productivity loss in idea-generating groups: tracking down the blocking effect. Journal of Personality and Social Psychology, 61(3), 392.

Dugosh C.; Paulus A. (2005). Cognitive and social comparison processes in brainstorming. Journal of Experimental Social Psychology, 41(3), 313-320.

Ernst, H. (2001). Erfolgsfaktoren neuer Produkte: Wissenschaftliche Ergebnisse Innovationserfolgspanel (leP), Vortrag im Diskussionkreis Forschungs- Entwicklungs-und Innovations management, (pp.315-327). Deutscher Universitätsverlag.

Flint, D. J. (2002). Compressing new product success-to-success cycle time: deep customer value understanding and idea generation. Industrial Marketing Management, 31(4), 305-315.

Flynn, M. et al. (2003). Idea management for organizational innovation. International Journal of Innovation Management, 7(4), 417-442.

Geschka, H., \& Schwarz-Geschka, M. (2000). Ideenmanagement und dessen Unterstützung durch eine Ideen- und Projektdatenbank. In Dold, E.\& Gentsch, P. (Ed.), Innovationsmanagement: handbuch für mittelständische Betriebe (pp. 99-114), Luchterhand, Neuwied, Germany.

Girotra, K., Terwiesch, C., \& Ulrich, K. T. (2010). Idea generation and the quality of the best idea. Management Science, 56(4), 591-605.

Koen, P. A. et al. (2001). Providing clarity and a common language to the "fuzzy front end". Research Technology Management, 44(2), 46-55.

Koen, P. et al. (2002). Fuzzy front end: effective methods, tools and techniques. Wiley, New York, NY.

Mcadam, R., \& Leonard, D. (2004). Reengineering based inquiry into innovation in the front end of new product and service development processes. International Journal of Product Development, 1(1), 66-91.

Mcadam, R., \& Mcclelland, J. (2002). Individual and team-based idea generation within innovation management: organizational and research agendas. European Journal of Innovation Management, 5(2), 86-97.

Miguez, V. B. (2012). Uma abordagem de geração de ideias para o processo de inovação. (Dissertação de Mestrado em Engenharia e Gestão do Conhecimento, Programa de Pós Graduação em Engenharia e Gestão do Conhecimento, Universidade Federal de Santa Catarina).

Montoya-Weis, M. M., \& Calantone, R. J. (1994). Determinants of new product performance: a review and meta-analysis. Journal of Product Innovation Management, 11(11), 397-417.

Organization for economic co-operation and development. (2012). Oslo Manual: guidelines for collecting and interpreting innovation data. 3. ed. Luxemburg: OECD, 2005. Retrievedfrom http://www.oecd.org.

Porcaro, R. M.(2001). A mensuração da economia eletrônica no sistema de informação estatística. Brasília: IBGE/DPE/Demet.

Reid, S. E., \& Brentani, U. (2004). The fuzzy front end of new product development for discontinuous innovation: a theoretical model. Journal of Product Innovation Management, 21(3), 170-184.

Reitzig, C. (2011). Productivity is not enough: a comparison of interactive and nominal brainstorming groups on idea generation and selection. Journal of Experimental Social Psicology, 42, 244-251.

Rochford, L. (1991). Generating and screening new product ideas. Industrial Marketing Management, 20(4), 287-296. 
Santos, A. R. (2000). Metodologia científica: a construção do conhecimento. 3. ed. Rio de Janeiro: DP\&A Editora.

Sensiper, S. et al. (2003). The Role of tacit knowledge in group Innovation. California Management Review, 40(3), 112-132.

Smith, P. G.. \& Reinertsen, D. G. (1991). Developing products in half the time. New York: Van Nostrand Reinhold.

Tidd, J., Bessant, J. \& Pavitt, K. (2008). Gestão da Inovação. 3. ed. Porto Alegre: Bookman.

Verworn, B. (2006). How German measurement and control firms integrate market and technological knowledge into the front end of new product development. International Journal of Technology Management, 34(3), 379-389.

Vygotsky, L. S. (2007). A formação social da mente. 7. ed. São Paulo: Martins Fontes.

Voigt, K. I.,\& Brem, A. (2005). Integriertes ideenmanagement als strategischer erfolgsfaktor junger technologieunternehmen. In Schwarz, E., \& Harms, R. (Ed.). Integriertes ideenmanagement- betriebliche und überbetriebliche aspekte unter besonderer berü cksichtigung kleiner und mittlerer unternehmen. Wiesbaden: Gabler. 